\title{
Effect of Boswellia serrata Resin Supplementation on Basic Chemical and Mineral Element Composition in the Muscles and Liver of Broiler Chickens
}

\author{
A. R. M. Al-Yasiry ${ }^{1,2}$ - B. Kiczorowska ${ }^{1}$ - W. Samolińska ${ }^{1}$
}

Received: 20 December 2016 / Accepted: 9 February 2017 / Published online: 16 February 2017

(C) The Author(s) 2017. This article is published with open access at Springerlink.com

\begin{abstract}
Supplementation of broiler chicken diets with resin rich in bioactive components, such as different boswellic acids, could improve productivity, chemical composition, and nutritive value of produced meat. The aim of the study was to assess the effect of different levels of Boswellia serrata (BSR) supplementation in broiler chicken diet on the basic chemical composition and the $\mathrm{Ca}, \mathrm{P}, \mathrm{Mg}, \mathrm{Fe}, \mathrm{Zn}$, and $\mathrm{Cu}$ contents in the breast and drumstick muscles and liver. The analyses involved 200 Ross 308 chickens. The broiler chickens were fed with diets containing 0 (BSR0), 1.5 (BSR1.5), 2 (BSR2), and 2.5\% (BSR2.5) of B. serrata resin. The supplementation of broiler chicken diets with $2.5 \%$ (BSR2.5) decreased linearly the ether extract in breast and drumstick muscles and the calorific value in drumstick muscles $(P<0.05)$. An increased level of $\mathrm{Ca}$ in the breast and drumstick muscles (control vs. BSR diets, linear, $P<0.05$ ) and in the liver (control vs. BSR diets, quadratic, $P<0.05$ ) as well as $\mathrm{Mg}$ in the drumstick muscles and liver (control vs. BSR diets, linear, $P<0.05$ ) was noted in the BSR2 and BSR2.5 chicken groups. The BSR supplementation reduced $\mathrm{Cu}$ (in the breast and drumstick muscles and liver) $(P<0.05)$ and $\mathrm{Zn}$ retention (in the drumstick muscles) (C vs. BSR, linear, $P<0.05)$. B. serrata resin can be considered a good feed additive with a positive impact on the dietary value of poultry meat.
\end{abstract}

B. Kiczorowska

bozena.kiczorowska@up.lublin.pl

1 Department of Bromatology and Food Physiology, Institute of Animal Nutrition and Bromatology, University of Life Science, Akademicka Street 13, 20-950 Lublin, Poland

2 Department of Animal Resources, University of Wasit, Al Kut, Wasit, Iraq
Keywords Broiler chicken $\cdot$ Meat $\cdot$ Liver $\cdot$ Mineral elements · Nutrients $\cdot$ Boswellia serrata

\section{Introduction}

Currently, consumers seek safe, high-quality food. They attach greater importance to the production procedures, which in animal production, including poultry industry, are associated with the quality of animal nutrition. A group of food additives that is safe to consumers' health and has a beneficial effect on the palatability and nutritional value of meat is phytobiotics [1]. The most popular plant supplements of feed mixtures include herbs and essential oils whose beneficial impact on the effectiveness of poultry production has already been comprehensively described in literature. The beneficial effect of phytobiotics in poultry nutrition is visible not only in improved health status but also in better production performance, e.g., higher weight gains, higher feed conversion rates, and improved nutritional and dietary values of meat. Additionally, phytobiotics increase the bioavailability of some micro- and macroelements, which are accumulated in tissues more easily. For instance, increased contents of $\mathrm{Mg}, \mathrm{Zn}$, and $\mathrm{Cu}$ were detected in poultry breast and thigh meat and in the liver [2-5]. Still, the poultry industry is seeking new nutrition solutions that can ensure a high level of production, which is inextricably associated with maintenance of a good health status of chickens throughout the feeding period. New phytobiotics, such as aromatic resins obtained from, e.g., trees of the genus Boswellia in the family Burseraceae, have appeared on the European market. So far, they have been applied in the traditional Ayurvedic medicine due to their anti-inflammatory, antiseptic, analgesic, antibacterial, anticancer, hepatoprotective, hypolipidemic, hypocholesterolemic, immunomodulatory, and antiproliferative action [6]. Such a broad 
spectrum of therapeutic properties of Boswellia serrata resin is ensured by the bioactive compounds contained therein. These include terpenes, with 11-keto- $\beta$-acetyl-beta-boswellic, acetyl-11-keto- $\beta$ - boswellic, and acetyl- $\alpha$ - boswellic acids characterized by the highest biological activity [7].

Although $B$. serrata resin jest a botanical feed additive approved for use in poultry production according to the European Union Register of Feed Additives pursuant to Regulation (EC) No 1831/2003 [8], its potential application in poultry production is investigated by few researchers. Their studies indicate beneficial effects of $B$. serrata resin supplementation of broiler chicken diets on the production performance of these birds. Improvement of the poultry breeding performance, i.e., better weight gains, higher feed conversion rates, and even carcass slaughter performance, is associated with improved digestibility of nutrients contained in the diet. This results from microbiological stabilization of the gastrointestinal tract by the activity of boswellic acids. It results in optimization of the processes of digestion and absorption in the small intestine [9-11]. Greater bioavailability of nutrients and minerals may have a significant impact on the chemical composition of tissues. Supplementation of broiler chicken diets with resin rich in bioactive components, such as different boswellic acids, could improve productivity as well as the chemical composition and nutritive value of produced meat. From the consumer's point of view, the greatest attention is focused on the nutrient content in tissues that are relevant for consumption, e.g., breast and thigh muscles or offal. The most popular element of offal is the liver, which is widely used in cookery. Therefore, the aim of the study was to determine the effect of different levels of $B$. serrata resin supplementation in diets for broiler chickens on the basic nutrients (dry matter, crude protein, ether extract, and crude ash), energy, and chosen mineral ( $\mathrm{Ca}, \mathrm{P}, \mathrm{Mg}, \mathrm{Fe}, \mathrm{Zn}$, and $\mathrm{Cu}$ ) content in the breast and drumstick muscles and liver.

\section{Materials and Methods}

\section{Birds, Diets, and Experimental Design}

Two hundred 1-day-old broiler chickens (Ross 308, Aviagen, Cracow, Malopolskie Province, Poland) were randomly assigned to four dietary treatments with five cages per treatment and five females and five males per cage. The experiment lasted 6 weeks. The basal feed diets were made from cereal meal middlings (wheat and corn) and post-extraction soybean meal as recommended [12]. The broiler chickens were fed with three types of diets: starter ( 0 to 21 days), grower (22 to 35 days), and finisher (36 to 42 days); the detailed composition of the diets in each stage of animal feeding is presented in Table 1. The starter diet was fed to the broiler chickens in a crumbled form, and the grower and finisher diets in a granulated form. The resin was obtained from B. serrata trees by incision of a barkless trunk and left to dry in natural conditions (direct information from the seller). Fragmented natural B. serrata resin (BSR) was obtained commercially (Baghdad, Iraq). The chemical composition of the resin comprised $95.34 \%$ dry matter, ash $1.59 \%$ dry matter, protein $2.65 \%$ dry matter, fat $63.88 \%$ dry matter, and $2.38 \%$ gum resin acetyl-11-keto- $\beta$-boswellic acid [9]. Dietary treatments consisted of the control (C) and the control supplemented with 1.5 (BSR1.5), 2 (BSR2), or 2.5\% (BSR2.5) of B. serrata resin. All the diets were iso-energetic and iso-nitrogenous.

One female broiler chicken and one male broiler chicken with the body weight close to the average were selected from each cage for the dissection, which was carried out according to the method described by Ziołecki and Doruchowski [13]. For slaughter analysis, the breast and drumstick muscles and liver were sampled and the basic nutrients and selected mineral elements were determined.

\section{Tissue Sampling Procedure and Chemical Analyses}

The tissue samples of the breast muscle (m. pectoralis major and $\mathrm{m}$. pectoralis minor), drumstick muscle (m. gastrocnemius, m. peroneus longus, and m. tibialis anterior), and liver were harvested immediately after slaughter, frozen at a temperature of $-18{ }^{\circ} \mathrm{C}$, and stored until chemical analyses. The muscles used in the analyses were without skin with the subcutaneous fat tissue. Three replicates of each sample were analyzed and the mean value was used in the data analyses. The contents of dry matter, total protein, ether extract, and crude ash were determined in the muscles and liver according to standard procedures [14]. The content of nutrients in the samples was expressed in grams per $100 \mathrm{~g}$ wet tissue. The energy value was estimated using net Atwater equivalents (considering protein and fat).

The contents of $\mathrm{Ca}, \mathrm{Mg}, \mathrm{Fe}, \mathrm{Zn}$, and $\mathrm{Cu}$ in the tissue and diets were measured (three replicates of each sample) using flame atomic absorption spectrophotometry (FAAS) (Unicam 939/959AA-6300, Shimadzu Corp., Tokyo, Japan), according to the Polish Norm PN-EN ISO 6869. Tissue samples, dried at $65{ }^{\circ} \mathrm{C}$ for the following $24 \mathrm{~h}$ and then at $105{ }^{\circ} \mathrm{C}$ for $24 \mathrm{~h}$, underwent combined mineralization in a muffle furnace at a temperature of $450{ }^{\circ} \mathrm{C}$ for $12 \mathrm{~h}$, using hydrogen peroxide as an oxidant. The resulting ash was dissolved in $1 \mathrm{M} \mathrm{HNO}_{3}$. Calcium was determined at $\lambda=422.7 \mathrm{~nm}$, magnesium at $\lambda=285.2 \mathrm{~nm}$, iron at $\lambda=248.3 \mathrm{~nm}$, zinc at $\lambda=213.9 \mathrm{~nm}$, and copper at $\lambda=324.8 \mathrm{~nm}$ [15]. The method accuracy was evaluated using minerals determined in the standard reference material chicken meat NCS ZC73016. Total P content was determined colorimetrically PN-76/R-64781 [16] with a Helios Alpha UV-vis apparatus (Spectronic Unicam, Leeds, UK). The content of macro- and microminerals in the samples was expressed in milligrams per $100 \mathrm{~g}$ wet tissue. 
Table 1 Dietary ingredients and the nutrient content of the experimental diets (as-fed basis)

\begin{tabular}{|c|c|c|c|c|c|c|c|c|c|c|c|c|}
\hline \multirow[t]{3}{*}{ Item } & \multicolumn{12}{|l|}{$\operatorname{Diets}^{\mathrm{a}}$} \\
\hline & \multicolumn{4}{|c|}{ Starter (1-21 days) } & \multicolumn{4}{|c|}{ Grower (22-35 days) } & \multicolumn{4}{|c|}{ Finisher (36-42 days) } \\
\hline & $\mathrm{C}$ & BSR1.5 & BSR2 & BSR2.5 & $\mathrm{C}$ & BSR1.5 & BSR2 & BSR2.5 & $\mathrm{C}$ & BSR1.5 & BSR2 & BSR2.5 \\
\hline \multicolumn{13}{|l|}{ Ingredients (\%) } \\
\hline Maize & 30.0 & 30.0 & 30.0 & 30.0 & 29.0 & 29.0 & 29.0 & 29.0 & 30.0 & 30.0 & 30.0 & 30.0 \\
\hline Wheat & 20.0 & 20.0 & 20.0 & 20.0 & 23.0 & 23.0 & 23.0 & 23.0 & 26.0 & 26.0 & 26.0 & 26.0 \\
\hline Soybean meal ( $46 \%$ crude protein) & 39.47 & 39.47 & 38.97 & 38.47 & 36.76 & 37.26 & 36.76 & 36.26 & 32.13 & 32.13 & 31.63 & 31.13 \\
\hline Boswellia serrata resin & - & 1.5 & 2.0 & 2.5 & - & 1.5 & 2.0 & 2.5 & - & 1.5 & 2.0 & 2.5 \\
\hline Soybean oil & 6.0 & 4.5 & 4.5 & 4.5 & 7.0 & 5.0 & 5.0 & 5.0 & 8 & 6.5 & 6.5 & 6.5 \\
\hline Dicalcium phosphate & 1.8 & 1.8 & 1.8 & 1.8 & 1.8 & 1.8 & 1.8 & 1.8 & 1.8 & 1.8 & 1.8 & 1.8 \\
\hline Limestone & 1.2 & 1.2 & 1.2 & 1.2 & 1.0 & 1.0 & 1.0 & 1.0 & 0.7 & 0.7 & 0.7 & 0.7 \\
\hline $\mathrm{NaCl}$ & 0.33 & 0.33 & 0.33 & 0.33 & 0.5 & 0.5 & 0.5 & 0.5 & 0.5 & 0.5 & 0.5 & 0.5 \\
\hline DL-methionine ${ }^{\mathrm{b}}$ & 0.36 & 0.36 & 0.36 & 0.36 & 0.33 & 0.33 & 0.33 & 0.33 & 0.33 & 0.33 & 0.33 & 0.33 \\
\hline L-lysine ${ }^{c}$ & 0.34 & 0.34 & 0.34 & 0.34 & 0.36 & 0.36 & 0.36 & 0.36 & 0.34 & 0.34 & 0.34 & 0.34 \\
\hline Vitamin-mineral premix ${ }^{\mathrm{d}}$ & 0.5 & 0.5 & 0.5 & 0.5 & 0.25 & 0.25 & 0.25 & 0.25 & 0.2 & 0.2 & 0.2 & 0.2 \\
\hline \multicolumn{13}{|l|}{ Chemical composition (g/kg) } \\
\hline $\mathrm{ME}_{\mathrm{n}}^{\mathrm{e}}(\mathrm{MJ} / \mathrm{kg})$ & 12.55 & 12.43 & 12.43 & 12.44 & 12.97 & 12.90 & 12.93 & 12.95 & 13.39 & 13.33 & 13.36 & 13.37 \\
\hline Crude protein & 212.0 & 211.0 & 212.0 & 212.0 & 192.0 & 192.0 & 193.0 & 193.0 & 185.0 & 185.0 & 185.0 & 185.0 \\
\hline Lys & 13.8 & 13.8 & 13.8 & 13.8 & 12.9 & 12.9 & 12.9 & 12.9 & 11.3 & 11.3 & 11.3 & 11.3 \\
\hline Met + cys & 10.5 & 10.5 & 10.5 & 10.5 & 9.8 & 9.8 & 9.8 & 9.8 & 9.0 & 9.0 & 9.0 & 9.0 \\
\hline $\mathrm{Na}$ & 1.7 & 1.7 & 1.7 & 1.7 & 1.7 & 1.7 & 1.7 & 1.7 & 1.7 & 1.7 & 1.7 & 1.7 \\
\hline Total calcium ${ }^{\mathrm{f}}$ & 9.77 & 9.77 & 9.76 & 9.74 & 8.97 & 8.99 & 8.97 & 8.95 & 7.75 & 7.75 & 7.73 & 7.72 \\
\hline Total phosphorus ${ }^{\mathrm{f}}$ & 7.31 & 7.31 & 7.29 & 7.26 & 7.24 & 7.27 & 7.24 & 7.22 & 7.14 & 7.14 & 7.11 & 7.08 \\
\hline Total magnesium ${ }^{\mathrm{f}}$ & 1.85 & 1.85 & 1.84 & 1.83 & 1.79 & 1.80 & 1.79 & 1.77 & 1.69 & 1.69 & 1.68 & 1.67 \\
\hline Total $\operatorname{iron}^{\mathrm{f}}(\mathrm{mg} / \mathrm{kg})$ & 424.34 & 424.34 & 423.41 & 422.48 & 413.35 & 414.28 & 413.35 & 412.42 & 395.7 & 395.7 & 394.77 & 393.84 \\
\hline $\operatorname{Total~zinc}^{\mathrm{f}}(\mathrm{mg} / \mathrm{kg})$ & 130.86 & 130.86 & 130.61 & 130.36 & 130.01 & 130.26 & 130.01 & 129.76 & 128.48 & 128.48 & 128.23 & 127.98 \\
\hline Total $\operatorname{copper}^{\mathrm{f}}(\mathrm{mg} / \mathrm{kg})$ & 18.05 & 18.05 & 17.97 & 17.89 & 17.65 & 17.73 & 17.65 & 17.57 & 17.00 & 17.00 & 16.92 & 16.84 \\
\hline
\end{tabular}

${ }^{\mathrm{a}}$ Treatments: $\mathrm{C}=$ control diet without Boswellia serrata resin (BSR) supplementation; BSR1.5 = diet with $1.5 \%$ BSR supplementation; BSR2 = diet with $2.0 \%$ BSR supplementation; BSR2.5 = diet with 2.5\% BSR supplementation

${ }^{\mathrm{b}}$ Evonik Degussa Gmbh, Essen, Germany (per kilogram of $990 \mathrm{~g}$ met)

${ }^{\mathrm{c}}$ Ajinomoto Eurolysine S.A.S., Amiens, France (per kilogram of $780 \mathrm{~g}$ lys)

${ }^{\mathrm{d}}$ Added minerals and vitamins per kilogram of starter diet: Mn, $100 \mathrm{mg} ; \mathrm{I}, 1 \mathrm{mg}$; Fe, $40 \mathrm{mg}$; Zn, $100 \mathrm{mg}$; Se, $0.15 \mathrm{mg}$; Cu, 10 mg; vitamin A, 15,000 IU; vitamin $\mathrm{D}_{3}, 5000 \mathrm{UI}$; vitamin $\mathrm{E}, 75 \mathrm{mg}$; vitamin $\mathrm{K}_{3}, 4 \mathrm{mg}$; vitamin $\mathrm{B}_{1}, 3 \mathrm{mg}$; vitamin $\mathrm{B}_{2}, 8$ mg; vitamin $\mathrm{B}_{6}, 5 \mathrm{mg}$; vitamin B12, $0.016 \mathrm{mg}$; biotin, $0.2 \mathrm{mg}$; folic acid, $2 \mathrm{mg}$; nicotic acid, $60 \mathrm{mg}$; pantothenic acid, $18 \mathrm{mg}$; choline, $1800 \mathrm{mg}$. Added minerals and vitamins per kilogram of grower diet: Mn, $100 \mathrm{mg}$; I, 1 mg; Fe, 40 mg; Zn, 100 mg; Se, 0.15 mg; Cu, 10 mg; vitamin A, 12,000 IU; vitamin $\mathrm{D}_{3}, 5000$ UI; vitamin E, 50 mg; vitamin $\mathrm{K}_{3}, 3 \mathrm{mg}$; vitamin $\mathrm{B}_{1}$, $2 \mathrm{mg}$; vitamin $\mathrm{B}_{2}, 6 \mathrm{mg}$; vitamin $\mathrm{B}_{6}, 4 \mathrm{mg}$; vitamin $\mathrm{B}_{12}, 0.016 \mathrm{mg}$; biotin, $0.2 \mathrm{mg}$; folic acid, $1.75 \mathrm{mg}$; nicotic acid, $60 \mathrm{mg}$; pantothenic acid, $18 \mathrm{mg}$; choline, $1600 \mathrm{mg}$. Added minerals and vitamins per kilogram of finisher diet: $\mathrm{Mn}, 100 \mathrm{mg}$; I, $1 \mathrm{mg} ; \mathrm{Fe}, 40 \mathrm{mg} ; \mathrm{Zn}, 100 \mathrm{mg} ; \mathrm{Se}, 0.15 \mathrm{mg} ; \mathrm{Cu}, 10 \mathrm{mg}$; vitamin $A$, $12,000 \mathrm{IU}$; vitamin $\mathrm{D}_{3}, 5000 \mathrm{UI}$; vitamin E, $50 \mathrm{mg}$; vitamin $\mathrm{K}_{3}, 2 \mathrm{mg}$; vitamin $\mathrm{B}_{1}, 2 \mathrm{mg}$; vitamin $\mathrm{B}_{2}, 5 \mathrm{mg}$; vitamin $\mathrm{B}_{6}, 3 \mathrm{mg}$; vitamin $\mathrm{B}_{12}$, $0.011 \mathrm{mg}$; biotin, $0.05 \mathrm{mg}$; folic acid, $1.5 \mathrm{mg}$; nicotic acid, $35 \mathrm{mg}$; pantothenic acid, $18 \mathrm{mg}$; choline, $1600 \mathrm{mg}$

${ }^{\mathrm{e}} \mathrm{ME}_{\mathrm{n}}=$ metabolizable energy $(\mathrm{ME})$ in the diets corrected to zero nitrogen balance

${ }^{\mathrm{f}}$ Analyzed values. Each value based on triplicate determinations

\section{Statistical Analysis}

The data obtained were elaborated with the ANOVA method using one-way analysis of variance $(\alpha=95 ; P<0.05)$ and calculating the mean values for the treatments $(\bar{x})$ and the standard error of the mean (SEM). Linear and quadratic polynomial contrasts were used to evaluate the effects of different dietary levels of $B$. serrata resin. The direction and intensity of the relationships between the level of $B$. serrata resin addition and the basic nutrients and mineral elements $\left(r_{1}\right)$ in analyzed tissues and between each basic nutrient and mineral content in the broiler chicken meat and liver were determined using Pearson correlation coefficients $\left(r_{2}\right)$. The significance of differences was determined with Statistica 10.0 software StatSoft Inc. [17]. 


\section{Results}

The range of the content of the basic nutrients determined in the breast and drumstick muscles and liver was typical for these tissues (Tables 2, 3, and 4). Similar concentrations of the basic nutrients, macroelements, and trace elements in muscles of broiler chickens were reported in the US National Nutrient Database for Standard Reference for raw chicken meat [18].

B. serrata resin (BSR2.5) supplementation at the level of $2.5 \%$ in broiler chicken diets decreased the ether extract in breast muscles (control vs. BSR diets, linear, $P<0.05$ ) (Table 2). The other nutrients determined in the muscles of chickens from all the treatment groups exhibited a similar level. Although there were no statistically significant differences in the energy value of the breast muscles of chickens supplemented with BSR, there was a strong negative correlation between the calorific value and the level of BSR supplementation $\left(r_{1}=-0.686\right)$. There was an effect of the $B$. serrata resin on the $\mathrm{Ca}$ (control vs. BSR diets, linear, $P<0.05$ ) and $\mathrm{Cu}$ (control vs. BSR diets, linear, $P<0.05$ ) contents in breast muscles (Table 2). Additionally, a strong correlation was found between the content of these mineral elements in the breast muscle and the BSR level in the chicken diets ( $r_{1}=0.865$ and $r_{1}=-0.841$, respectively). The $\mathrm{P}, \mathrm{Mg}, \mathrm{Fe}$, and $\mathrm{Zn}$ contents in the breast muscles of the broiler chickens remained at a similar level, regardless of the application and the amount of the supplement. Simultaneously, the $\mathrm{Zn}$ content was positively correlated with the level of BRS supplementation $\left(r_{1}=0.586\right)$.
As in the case of the breast muscles, the addition of $B$. serrata resin to the broiler chicken diets decreased the ether extract in the drumstick muscles (control vs. BSR diets, linear, $P<0.05$ ) (Table 3). These changes were reflected in the calorific value of the drumstick muscles (control vs. BSR diets, linear, $P<0.05$ ). The increasing proportion of BSR in the broiler chicken diets had a beneficial effect on the dietary parameters of the drumstick muscles, which was confirmed by the estimated correlation coefficients: $r_{1}=-0.945$ (ether extract) and $r_{1}=0.971$ (energy). The drumstick muscles of broiler chickens fed with BSR supplementation were characterized by a higher level of $\mathrm{Ca}$ and $\mathrm{Mg}$ (control vs. BSR diets, linear, $P<0.05$ ) and lower contents of $\mathrm{Zn}$ and $\mathrm{Cu}$ (control vs. BSR diets, linear, $P<0.05$ ), compared with the muscles of the broiler chickens in the $\mathrm{C}$ treatments. Additionally, the amount of $\mathrm{Zn}$ and $\mathrm{Cu}$ microelements in the drumstick muscles was accumulated in inverse proportion to the BSR level in the chicken diet $\left(r_{1}=-0.745\right.$ and $r_{1}=-0.830$, respectively).

No changes in the nutrient content were noted in the analyzed livers (Table 4). The BSR supplementation altered liver $\mathrm{Ca}, \mathrm{Mg}$, and $\mathrm{Cu}$ accumulations in the broilers at 42 days of age $(P<0.05)$. Compared with the control treatment, the inclusion of BSR significantly increased $\mathrm{Ca}$ and $\mathrm{Mg}$ accumulation in the liver (respectively, control vs. BSR diets, quadratic, $P<0.05$; $r_{1}=0.713$ and control vs. BSR diets, linear, $P<0.05$; $\left.r_{1}=0.521\right)$. In turn, the content of $\mathrm{Cu}$ decreased in the liver with the increasing BSR level (control vs. BSR diets, quadratic, $\left.P<0.05 ; r_{1}=-0.776\right)$. The BSR treatments did not have a significant effect on retention of the other micro- and macroelements determined.

Table 2 Content of basic nutrients and mineral elements in the breast muscle of broiler chickens

\begin{tabular}{|c|c|c|c|c|c|c|c|c|}
\hline \multirow[t]{2}{*}{ Item } & \multicolumn{4}{|c|}{ Treatment $^{\mathrm{a}}$} & \multicolumn{4}{|c|}{ Statistical parameters } \\
\hline & $\mathrm{C}$ & BSR1.5 & BSR2 & BSR2.5 & SEM & $P$ value $\mathrm{C}$ vs. $\mathrm{BSR}$ & Linear & Quadratic \\
\hline \multicolumn{9}{|l|}{ Basic nutrients (g $\left.100 \mathrm{~g}^{-1}\right)$} \\
\hline Dry matter & 25.89 & 26.08 & 26.17 & 26.18 & 0.67 & 0.123 & 0.578 & 0.674 \\
\hline Crude protein & 23.72 & 23.46 & 23.15 & 23.09 & 0.61 & 0.264 & 0.315 & 0.418 \\
\hline Ether extract & 1.03 & 1.07 & 1.11 & 0.95 & 0.03 & 0.037 & 0.293 & 0.175 \\
\hline Crude ash & 1.12 & 1.09 & 1.14 & 1.13 & 0.07 & 0.319 & 0.214 & 0.378 \\
\hline Energy (kcal $100 \mathrm{~g}^{-1}$ ) & 104.23 & 103.47 & 102.59 & 100.91 & 11.64 & 0.139 & 0.178 & 0.568 \\
\hline \multicolumn{9}{|c|}{ Mineral elements (mg $100 \mathrm{~g}^{-1}$ ) } \\
\hline $\mathrm{Ca}$ & 28.02 & 29.21 & 31.14 & 30.65 & 0.45 & 0.016 & 0.023 & 0.516 \\
\hline $\mathrm{P}$ & 240.01 & 241.12 & 238.43 & 237.25 & 21.16 & 0.264 & 0.119 & 0.367 \\
\hline $\mathrm{Mg}$ & 16.43 & 16.24 & 16.34 & 16.17 & 0.06 & 0.128 & 0.248 & 0.438 \\
\hline $\mathrm{Fe}$ & 0.473 & 0.463 & 0.447 & 0.451 & $<0.01$ & 0.091 & 0.078 & 0.248 \\
\hline $\mathrm{Zn}$ & 0.496 & 0.506 & 0.513 & 0.521 & $<0.01$ & 0.148 & 0.487 & 0.569 \\
\hline $\mathrm{Cu}$ & 0.045 & 0.041 & 0.034 & 0.033 & $<0.01$ & 0.033 & 0.024 & 0.196 \\
\hline
\end{tabular}

Data represent the mean of ten broiler chickens per treatment

${ }^{\mathrm{a}}$ Treatments: $\mathrm{C}=$ control diet without Boswellia serrata supplementation; BSR1.5 = diet with $1.5 \%$ B. serrata supplementation; BSR2 = diet with $2 \%$ B. serrata supplementation; BSR2.5 = diet with $2.5 \%$ B. serrata supplementation 
Table 3 Content of basic nutrients and mineral elements in the drumstick muscle of broiler chickens

\begin{tabular}{|c|c|c|c|c|c|c|c|c|}
\hline \multirow[t]{2}{*}{ Item } & \multicolumn{4}{|c|}{ Treatment $^{\mathrm{a}}$} & \multicolumn{4}{|c|}{ Statistical parameters } \\
\hline & $\mathrm{C}$ & BSR1.5 & BSR2 & BSR2.5 & SEM & $\begin{array}{l}P \text { value } \\
\mathrm{C} \text { vs. BSR }\end{array}$ & Linear & Quadratic \\
\hline \multicolumn{9}{|l|}{ Basic nutrients (g $100 \mathrm{~g}^{-1}$ ) } \\
\hline Dry matter & 26.04 & 25.54 & 26.04 & 26.23 & 0.38 & 0.164 & 0.297 & 0.458 \\
\hline Crude protein & 19.32 & 18.84 & 18.91 & 18.23 & 0.57 & 0.109 & 0.187 & 0.238 \\
\hline Ether extract & 5.69 & 5.63 & 5.15 & 4.84 & 0.04 & 0.026 & 0.048 & 0.267 \\
\hline Crude ash & 1.03 & 1.01 & 0.98 & 0.96 & 0.06 & 0.192 & 0.248 & 0.549 \\
\hline Energy (kcal $100 \mathrm{~g}^{-1}$ ) & 128.49 & 126.03 & 121.95 & 116.48 & 12.34 & 0.035 & 0.036 & 0.248 \\
\hline \multicolumn{9}{|c|}{ Mineral elements (mg $\left.100 \mathrm{~g}^{-1}\right)$} \\
\hline $\mathrm{Ca}$ & 8.07 & 8.25 & 8.76 & 8.39 & 0.33 & 0.041 & 0.027 & 0.349 \\
\hline $\mathrm{P}$ & 194.12 & 197.43 & 201.47 & 209.02 & 19.36 & 0.089 & 0.054 & 0.129 \\
\hline $\mathrm{Mg}$ & 21.11 & 22.07 & 22.56 & 23.78 & 0.04 & 0.024 & 0.019 & 0.467 \\
\hline $\mathrm{Fe}$ & 0.647 & 0.649 & 0.648 & 0.653 & 0.02 & 0.139 & 0.346 & 0.247 \\
\hline $\mathrm{Zn}$ & 1.520 & 1.507 & 1.479 & 1.434 & 0.05 & 0.027 & 0.029 & 0.178 \\
\hline $\mathrm{Cu}$ & 0.078 & 0.073 & 0.062 & 0.051 & $<0.01$ & 0.016 & 0.018 & 0.331 \\
\hline
\end{tabular}

Data represent the mean of ten broiler chickens per treatment

${ }^{\mathrm{a}}$ Treatments: $\mathrm{C}=$ control diet without Boswellia serrata supplementation; BSR1.5 = diet with $1.5 \%$ B. serrata supplementation; BSR2 = diet with $2 \%$ B. serrata supplementation; BSR2.5 = diet with $2.5 \%$ B. serrata supplementation

The values of the correlation coefficients $\left(r_{2}\right)$ between basic nutrients and some elements in the breast and drumstick muscles and liver of chicken broilers supplemented with BSR are presented in Tables 5 and 6. Strong correlations were found between the content of the individual basic nutrients and elements in the muscles. A high negative correlation $\left(r_{2}>-0.7\right)$ was observed in the case of the following pairs: $\mathrm{Ca}-\mathrm{Ca}, \mathrm{Zn} ; \mathrm{P}-\mathrm{Mg}$, $\mathrm{Fe}$, crude ash; $\mathrm{Cu}-\mathrm{Mg}$; Fe-Mg, P, Fe, crude ash; Zn-dry matter; dry matter-Mg, Fe, crude ash; crude protein-crude protein, crude ash; ether extract-Mg, $\mathrm{P}, \mathrm{Fe}$, crude protein, crude ash; and crude

Table 4 Content of basic nutrients and mineral elements in the liver of broiler chickens

\begin{tabular}{|c|c|c|c|c|c|c|c|c|}
\hline \multirow[t]{2}{*}{ Item } & \multicolumn{4}{|c|}{ Treatment $^{\mathrm{a}}$} & \multicolumn{4}{|c|}{ Statistical parameters } \\
\hline & $\mathrm{C}$ & BSR1.5 & BSR2 & BSR2.5 & SEM & $\begin{array}{l}P \text { value } \mathrm{C} \\
\text { vs. BSR }\end{array}$ & Linear & Quadratic \\
\hline \multicolumn{9}{|l|}{ Basic nutrients (g $100 \mathrm{~g}^{-1}$ ) } \\
\hline Dry matter & 23.36 & 23.43 & 23.70 & 24.71 & 0.43 & 0.098 & 0.079 & 0.273 \\
\hline Crude protein & 19.12 & 19.22 & 19.33 & 20.16 & 0.31 & 0.167 & 0.487 & 0.349 \\
\hline Ether extract & 2.99 & 3.05 & 3.08 & 3.13 & 0.02 & 0.234 & 0.189 & 0.647 \\
\hline Crude ash & 1.23 & 1.22 & 1.21 & 1.23 & 0.09 & 0.109 & 0.378 & 0.458 \\
\hline Energy (kcal $100 \mathrm{~g}^{-1}$ ) & 103.39 & 104.33 & 105.04 & 108.81 & 14.31 & 0.213 & 0.077 & 0.389 \\
\hline \multicolumn{9}{|c|}{ Mineral elements (mg $\left.100 \mathrm{~g}^{-1}\right)$} \\
\hline $\mathrm{Ca}$ & 23.45 & 23.16 & 24.23 & 25.89 & 0.52 & 0.044 & 0.187 & 0.026 \\
\hline $\mathrm{P}$ & 317.23 & 324.61 & 334.72 & 341.50 & 26.48 & 0.067 & 0.093 & 0.647 \\
\hline $\mathrm{Mg}$ & 19.47 & 19.78 & 20.34 & 21.63 & 0.46 & 0.037 & 0.034 & 0.288 \\
\hline $\mathrm{Fe}$ & 4.63 & 4.59 & 4.53 & 4.48 & 0.21 & 0.119 & 0.458 & 0.394 \\
\hline $\mathrm{Zn}$ & 3.87 & 3.91 & 3.96 & 4.09 & 0.16 & 0.256 & 0.349 & 0.261 \\
\hline $\mathrm{Cu}$ & 0.67 & 0.69 & 0.53 & 0.49 & 0.02 & 0.023 & 0.189 & 0.039 \\
\hline
\end{tabular}

Data represent the mean of ten broiler chickens per treatment

${ }^{\mathrm{a}}$ Treatments: $\mathrm{C}=$ control diet without Boswellia serrata supplementation; BSR1.5 = diet with $1.5 \%$ B. serrata supplementation; BSR2 = diet with $2 \%$ B. serrata supplementation; BSR2.5 = diet with $2.5 \%$ B. serrata supplementation 
Table 5 Correlation coefficients between basic nutrients and mineral elements in the breast and drumstick muscles of BSR-supplemented broiler chickens $\left(r_{2}\right)$, significance values $P<0.05$

\begin{tabular}{|c|c|c|c|c|c|c|c|c|c|c|c|}
\hline & & \multicolumn{10}{|c|}{ Breast muscles } \\
\hline & & $\mathrm{Ca}$ & $\mathrm{Mg}$ & $\mathrm{P}$ & $\mathrm{Cu}$ & $\mathrm{Fe}$ & $\mathrm{Zn}$ & Dry matter & $\begin{array}{l}\text { Crude } \\
\text { protein }\end{array}$ & $\begin{array}{l}\text { Ether } \\
\text { extract }\end{array}$ & Crude ash \\
\hline \multirow{10}{*}{$\begin{array}{r}\text { Drumstick } \\
\text { muscles }\end{array}$} & $\mathrm{Ca}$ & -0.901 & 0.788 & ns & $\mathrm{ns}$ & 0.762 & ns & ns & 0.675 & 0.963 & ns \\
\hline & $\mathrm{Mg}$ & 0.929 & -0.687 & -0.771 & -0.767 & -0.767 & ns & -0.952 & -0.670 & -0.915 & $\mathrm{~ns}$ \\
\hline & $\mathrm{P}$ & $\mathrm{ns}$ & -0.628 & -0.699 & ns & -0.799 & ns & $\mathrm{ns}$ & $\mathrm{ns}$ & -0.893 & $\mathrm{~ns}$ \\
\hline & $\mathrm{Cu}$ & 0.731 & $\mathrm{~ns}$ & ns & $\mathrm{ns}$ & 0.733 & ns & ns & $\mathrm{ns}$ & 0.697 & -0.778 \\
\hline & $\mathrm{Fe}$ & 0.830 & -0.645 & -0.769 & ns & -0.866 & ns & -0.870 & $\mathrm{~ns}$ & -0.896 & $\mathrm{~ns}$ \\
\hline & $\mathrm{Zn}$ & -0.776 & 0.896 & 0.725 & ns & ns & -0.677 & 0.801 & ns & 0.799 & ns \\
\hline & Dry matter & ns & ns & ns & 0.858 & $\mathrm{~ns}$ & -0.824 & $\mathrm{~ns}$ & $\mathrm{~ns}$ & ns & -0.843 \\
\hline & Crude protein & 0.812 & -0.798 & $\mathrm{~ns}$ & ns & -0.610 & ns & ns & -0.814 & -0.886 & ns \\
\hline & Ether extract & -0.659 & $\mathrm{~ns}$ & ns & 0.706 & 0.954 & ns & ns & ns & 0.741 & ns \\
\hline & Crude ash & 0.664 & ns & -0.811 & ns & -0.807 & ns & -0.818 & -0.620 & -0.839 & $\mathrm{~ns}$ \\
\hline
\end{tabular}

$n s$ no statistical significance

ash-Cu, dry (breast-drumstick muscles, respectively; $P<0.05$ ) (Table 5). Strong positive correlations $\left(r_{2}>0.7\right)$ were noted for $\mathrm{Ca}-\mathrm{Mg}, \mathrm{Cu}, \mathrm{Fe}$, crude protein; $\mathrm{Mg}-\mathrm{Ca}, \mathrm{Zn} ; \mathrm{P}-\mathrm{Zn}$; Cu-dry matter, ether extract; $\mathrm{Fe}-\mathrm{Ca}, \mathrm{Cu}$, ether extract; dry matter-Zn; and ether extract-Ca, $\mathrm{Zn}$, ether extract (breast-drumstick muscles, respectively; $P<0.05$ ).

Table 6 Correlation coefficients between basic nutrients and mineral elements in the liver and the breast and drumstick muscles of BSR-supplemented broiler chickens $\left(r_{2}\right)$, significance values $P<0.05$

\begin{tabular}{|c|c|c|c|c|c|c|c|c|c|c|c|}
\hline & & \multicolumn{10}{|l|}{ Liver } \\
\hline & & $\mathrm{Ca}$ & $\mathrm{Mg}$ & $\mathrm{P}$ & $\mathrm{Cu}$ & $\mathrm{Fe}$ & $\mathrm{Zn}$ & Dry matter & $\begin{array}{l}\text { Crude } \\
\text { protein }\end{array}$ & $\begin{array}{l}\text { Ether } \\
\text { extract }\end{array}$ & Crude ash \\
\hline \multirow[t]{10}{*}{ Breast muscles } & $\mathrm{Ca}$ & ns & ns & $\mathrm{ns}$ & $\mathrm{ns}$ & ns & $\mathrm{ns}$ & $\mathrm{ns}$ & 0.684 & 0.613 & ns \\
\hline & $\mathrm{Mg}$ & -0.897 & $\mathrm{~ns}$ & $\mathrm{~ns}$ & $\mathrm{~ns}$ & $\mathrm{~ns}$ & $\mathrm{~ns}$ & -0.646 & -0.715 & $\mathrm{~ns}$ & ns \\
\hline & $\mathrm{P}$ & -0.777 & -0.793 & -0.899 & 0.782 & 0.824 & -0.896 & -0.670 & $\mathrm{~ns}$ & -0.781 & -0.760 \\
\hline & $\mathrm{Cu}$ & -0.754 & -0.806 & -0.857 & 0.897 & 0.737 & -0.790 & ns & $\mathrm{ns}$ & -0.851 & ns \\
\hline & $\mathrm{Fe}$ & -0.778 & $\mathrm{~ns}$ & -0.702 & 0.786 & 0.826 & -0.697 & -0.648 & -0.756 & -0.782 & ns \\
\hline & $\mathrm{Zn}$ & 0.876 & $\mathrm{~ns}$ & 0.846 & -0.972 & -0.799 & 0.940 & 0.714 & ns & 0.672 & ns \\
\hline & Dry matter & $\mathrm{ns}$ & $\mathrm{ns}$ & $\mathrm{ns}$ & $\mathrm{ns}$ & $\mathrm{ns}$ & ns & ns & -0.948 & $\mathrm{~ns}$ & $\mathrm{~ns}$ \\
\hline & Crude protein & ns & ns & $\mathrm{ns}$ & $\mathrm{ns}$ & $\mathrm{ns}$ & $\mathrm{ns}$ & ns & ns & ns & ns \\
\hline & Ether extract & -0.801 & -0.638 & $\mathrm{~ns}$ & ns & 0.683 & -0.870 & -0.603 & -0.761 & -0.812 & ns \\
\hline & Crude ash & 0.669 & $\mathrm{~ns}$ & 0.825 & -0.929 & ns & $\mathrm{ns}$ & $\mathrm{ns}$ & ns & 0.655 & $\mathrm{~ns}$ \\
\hline \multirow{10}{*}{$\begin{array}{r}\text { Drumstick } \\
\text { muscles }\end{array}$} & $\mathrm{Ca}$ & -0.611 & -0.686 & $\mathrm{~ns}$ & -0.611 & ns & $\mathrm{ns}$ & -0.754 & -0.813 & -0.626 & ns \\
\hline & $\mathrm{Mg}$ & 0.617 & 0.692 & $\mathrm{~ns}$ & $\mathrm{~ns}$ & ns & $\mathrm{ns}$ & 0.759 & 0.817 & 0.632 & ns \\
\hline & $\mathrm{P}$ & 0.785 & 0.897 & 0.616 & -0.807 & -0.839 & 0.699 & 0.813 & $\mathrm{~ns}$ & 0.788 & 0.733 \\
\hline & $\mathrm{Cu}$ & -0.788 & -0.667 & -0.897 & 0.755 & 0.876 & -0.960 & $\mathrm{~ns}$ & -0.613 & $\mathrm{~ns}$ & $\mathrm{~ns}$ \\
\hline & $\mathrm{Fe}$ & 0.743 & 0.806 & ns & ns & -0.614 & $\mathrm{~ns}$ & 0.860 & 0.604 & 0.782 & 0.682 \\
\hline & $\mathrm{Zn}$ & -0.822 & -0.874 & -0.665 & ns & 0.709 & -0.887 & -0.718 & -0.651 & -0.850 & -0.650 \\
\hline & Dry matter & -0.680 & -0.604 & ns & 0.734 & 0.798 & 0.798 & $\mathrm{~ns}$ & ns & $\mathrm{ns}$ & $\mathrm{ns}$ \\
\hline & Crude protein & $\mathrm{ns}$ & 0.520 & ns & $\mathrm{ns}$ & ns & ns & ns & 0.674 & $\mathrm{~ns}$ & $\mathrm{~ns}$ \\
\hline & Ether extract & -0.696 & -0.981 & ns & 0.635 & 0.897 & -0.675 & $\mathrm{~ns}$ & ns & -0.794 & $\mathrm{~ns}$ \\
\hline & Crude ash & 0.667 & 0.738 & $\mathrm{~ns}$ & ns & ns & 0.756 & 0.800 & 0.631 & 0.681 & $\mathrm{~ns}$ \\
\hline
\end{tabular}

$n s$ no statistical significance value 
Strong inversely proportional correlations $\left(r_{2}>-0.7\right)$ were determined in the case of $\mathrm{Ca}-\mathrm{Mg}, \mathrm{P}, \mathrm{Cu}, \mathrm{Fe}$, ether extract; $\mathrm{Mg}$ $\mathrm{P}, \mathrm{Cu}$; P-P, $\mathrm{Cu}, \mathrm{Fe} ; \mathrm{Cu}-\mathrm{Zn}$, crude ash; Fe-Zn; $\mathrm{Zn}-\mathrm{P}, \mathrm{Cu}$, ether extract; crude protein- $\mathrm{Mg}, \mathrm{Fe}$, dry matter, ether extract; ether extract- $\mathrm{P}, \mathrm{Cu}, \mathrm{Fe}$, ether extract; and crude ash-P between the liver and breast muscles $(P<0.05)$ and between the liver and drumstick muscles: $\mathrm{Ca}-\mathrm{Cu}, \mathrm{Zn} ; \mathrm{Mg}-\mathrm{Zn}$, ether extract; $\mathrm{P}-\mathrm{Cu}$; $\mathrm{Cu}-\mathrm{P}$; Fe-P; dry matter-Ca, $\mathrm{Zn}$; crude protein-Ca; and ether extract-Zn, ether extract $(P<0.05)$ (Table 6). In turn, there were high positive correlations $\left(r_{2}>0.7\right)$ between the contents of mineral elements and nutrients in the liver and breast muscles: $\mathrm{Ca}-\mathrm{Zn}$; $\mathrm{P}-\mathrm{Zn}$, crude ash; $\mathrm{Cu}-\mathrm{P}, \mathrm{Cu}, \mathrm{Fe}$; Fe-P, Cu, Fe; Zn$\mathrm{Zn}$; and dry matter-Zn $(P<0.05)$ and in the liver and drumstick muscles: $\mathrm{Ca}-\mathrm{P}, \mathrm{Fe}$; $\mathrm{Mg}-\mathrm{P}, \mathrm{Fe}$, crude ash; $\mathrm{Cu}-\mathrm{Cu}$, dry matter, ether extract; Fe-Cu, Zn, dry matter; Zn-dry matter, crude ash; dry matter-Mg, $\mathrm{P}, \mathrm{Fe}$, crude ash; crude protein$\mathrm{Mg}$; and ether extract-P, Fe and crude ash-P $(P<0.05)$.

\section{Discussion}

Higher dietary values of the poultry meat resulting from the BSR supplementation of broiler chicken diets were noted in all the analyzed tissues, i.e., both in the meat and liver. The decreased content of crude fat in the broiler chicken tissues and, hence, its reduced calorific value may be associated with the anti-inflammatory and bacteriostatic properties of the most active components, i.e., boswellic acids [19, 20]. Although there are no investigations concerning the potential application of BSR in animal production, laboratory analyses prove that $B$. serrata resin and its extracts can have a significant effect on lipid metabolism in animals. Tests carried out on rats have revealed a positive impact of the use of this type of supplementation, i.e., reduction of the serum cholesterol and triglyceride levels [21]. Additionally, researchers have shown that $B$. serrata can stimulate the function of the thyroid, leading to metabolic upregulation and increased calorie burning. The beneficial effect of $B$. serrata on the cholesterol and triglyceride levels is also related to improvement in liver function, which can result in reduction of cholesterol biosynthesis and stimulation of transformation of cholesterol into bile acids. Although the exact mechanisms of action have not been elucidated yet, these results prove the positive impact of $B$. serrata on animal health and the quality of food products of animal origin. B. serrata is beginning to arouse researchers' interest due to its potential therapeutic and dietary applications in humans, e.g., in the treatment of diabetes or even obesity [22-24].

The improvement in the dietary value of the breast and drumstick muscle and liver can also be associated with the antioxidant and immunomodulatory activity of boswellic acid, which has a beneficial impact on stabilization of the gastrointestinal microbial flora [25]. In their previous investigations, the authors observed a positive effect of BSR on the structure of intestinal villi, gastrointestinal microbiome, and health status in broiler chickens, which was reflected in higher feed nutrient intake and greater rearing performance [9, 10]. There are no scientific reports on the effect of the BSR active compounds on mineral metabolism in animals; yet, investigations on the application of various phytobiotics (herbs, essential oils, and oleoresins) in poultry nutrition confirm the influence of these additives on the level of element retention in tissues and their status in the organism. The mechanisms of phytobiotics include alteration in the gastrointestinal functions, induction and inhibition of metabolic enzymes, beneficial modification in the intestinal microbiota, increased digestibility and nutrient absorption, histological modifications of the gastrointestinal tract, and even stimulation of appetite [9, 10, 26-29].

The presence of BSR in broiler chicken diets, in particular at the levels of 2 and $2.5 \%$, increased the $\mathrm{Ca}$ and $\mathrm{P}$ contents in the muscle tissues of the broiler chickens. An optimal level of these elements in the organism determines, e.g., a normal course of digestive processes and maintenance of appropriate homeostasis in the broiler organism [30]. The high Ca content in the broiler chicken meat accompanied by reduced fat content may be nutritionally advantageous. The analyzed tissues, i.e., the breast and drumstick muscles and liver, exhibited negative correlations between the $\mathrm{Ca}$ content and the ether extract $\left(r_{2}>0.6\right)$. Calcium compounds and fat in the gastrointestinal tract can form insoluble products that block $\mathrm{Ca}$ availability on the one hand and impair the digestive availability of fat on the other hand, which can be taken advantage of in body-weight reduction diets [31, 32]. Increased Mg levels were noted in the drumstick muscles of the BSRsupplemented broiler chickens. This element is mainly accumulated in bones; in tissues, $\mathrm{Mg}$ is involved in neuronal and cardiac muscle excitability, release of hormones and neurotransmitters, and normal muscle contractility, as it is responsible, together with $\mathrm{Ca}$, for normal muscle function. In birds, $\mathrm{Mg}$ deficiency leads to muscle weakness, tremors, or even spasms, which indicates health problems in the flock and results in reduced productivity $[33,34]$. A high correlation between the contents of these elements was found in the case of the analyzed breast and drumstick muscles, which seems to be advantageous for breeding performance (Ca-Mg: $r_{2}=0.929$ and Mg-Ca: $r_{2}=0.788$ ). The increased levels of these elements in the muscles of the broiler chickens may have resulted in improved overall health status and production performance, which was reported by the authors in their previous study [10].

All the tissues were characterized by a reduced level of the analyzed microelements: $\mathrm{Cu}$ (muscles and liver), $\mathrm{Fe}$ (breast muscle and liver), and $\mathrm{Zn}$ (drumstick muscle). Besides their specific biochemical role, the elements cooperate to protect cells against excess amounts of free oxygen radicals, regulate the activity of cellular enzymes, and reinforce the 
hematopoietic role of $\mathrm{Fe}[35,36]$. However, despite the reduction of their level in the tissues, no health deterioration was observed in birds studied previously. On the contrary, beneficial effects of BSR supplementation on weight gain and dressing percentage or better feed conversion rates were noted [10]. As indicated in the literature, these effects are also observed in the case of reduced bioavailability of these elements [37-39]. This prompts new areas of research aimed at investigating whether BSR supplementation can contribute to enhancement of mineral bioavailability in feed. Mohite et al. [40] and Surai [41] suggest that enhanced bioavailability of minerals may also result from reduction in the concentration of polyphenols, flavonoids, and tannins in the gastrointestinal tract associated with microbial fermentation. The effect of phytobiotics on mineral metabolism in the broiler chicken organism can be multidirectional. Similar to the present study, reduction of $\mathrm{Fe}$ levels in chicken breast muscles caused by supplementation with aqueous herbal extracts (Galega [Herb. Galegae], stinging nettle [Herb. Utricae], lemon balm [Fol. Melissae], and sage [Fol. Salviae]) was reported by Wójcik et al. [42]. Similar results were reported by Starčević et al. [43], who supplemented broiler chicken diets with active compounds isolated from phytobiotics, i.e., thymol, tannic acid, and gallic acid. In turn, Giannenas et al. [44], who used oregano essential oil and laurel essential oil as feed additives, did not observe changes in the content of $\mathrm{Cu}$ and $\mathrm{Zn}$ in breast and thigh meat. The differences in the impact of phytobiotics on retention of trace elements in animal muscles are associated with the high diversity of the phytobiotic active compounds, i.e., terpenoids (mono- and sesquiterpenes, steroids, etc.), alkaloids (alcohols, aldehydes, ketones, esters, ethers, lactones, etc.), glycosides, and phenolics (tannins). They can exert different effects on the availability of mineral components [26, 27, 29, 45, 46].

Interactions in the content of nutrients in the animal organisms depend on the species, breed, sex, rearing system, health status, and the physiological-biochemical function of muscles and organs [47-49]. The interrelations between nutrients in the organism are strongly influenced by their content and availability in the diet as well as the status of the gastrointestinal microbiome, which can be optimized by application of appropriate dietary additives $[5,10,50,51]$. In the investigations conducted by Herkel et al. [5], significant correlations were found between dry matter with crude protein and fat in breast and thigh muscles of fattening turkeys fed with a diet supplemented with a blend of essential oils from origanum, anise, and citrus fruits and fructooligosaccharides. The present study did not reveal such an effect of $B$. serrata resin on the interactions between nutrients in the muscles. Herkel et al. [5] also recorded positive correlations between ash and phosphorus, ash and copper, and ash and iron $(P<0.01)$. Such significant correlations between ash and minerals in the breast and drumstick muscles (crude ash-Cu; P-crude ash; Fe-crude ash) were found in this study, but they were reverse. Among the determined nutrients, significant correlations were most frequently found between the mineral elements and ether extract. They were usually negative and were noted mainly for $\mathrm{Mg}, \mathrm{P}$, and Fe. The results may suggest that the accumulation of mineral elements in the muscles and liver was higher at the lower fat content, which can undoubtedly increase the nutritional values of meat. However, further research in this area is indispensable to confirm these correlations. High correlations were noted between the levels of mineral elements in the breast and drumstick muscles; they were especially strong in the case of the $\mathrm{Ca}, \mathrm{Mg}, \mathrm{P}$, and $\mathrm{Fe}$ contents. Poltowicz and Doktor [52] report that $\mathrm{Mg}$ in the poultry muscle tissue regulates the level of intracellular $\mathrm{Ca}$ and $\mathrm{P}$; they noted especially strong Mg-P correlations. These correlations had a significant effect on the meat processing quality, as they regulated the water retention capacity of the analyzed meat. A strong correlation between $\mathrm{Fe}-\mathrm{Cu}, \mathrm{Cu}-\mathrm{Cu}$, and $\mathrm{Cu}-\mathrm{Zn}$ in the breast and drumstick muscles of chickens fed with diets supplemented with various phytobiotics was reported by Stef et al. [27]. These results, however, confirm the great diversity of mechanisms regulating retention of mineral elements in the organism of broiler chickens, as the BSR supplementation analyzed in the present study did not cause such correlations. The strong correlations between basic nutrient and mineral elements in the breast and drumstick muscles observed in the present study may be an effect of the improvement of digestibility stimulated by the addition of BSR in the diets [10]. This effect may differentiate the chemical composition of leg and breast muscles. Greater intensity of these changes was noted for the leg muscles. Chicken breast and leg muscles differ substantially in their histochemical profile and the character of metabolic processes. Similar differences in the levels of minerals in breast and leg muscles were reported by Zapata et al. [48] and Goluch et al. [53]. In the present study, there were clear correlations with the same direction between the components of the analyzed muscles $(\mathrm{Ca}-\mathrm{Mg}, \mathrm{Mg}-\mathrm{Ca}$, crude protein-Ca, crude protein- $\mathrm{Mg}$, Ca-crude protein, and $\mathrm{Mg}$-crude protein), which may have been related to their important role in enzymatic processes and their impact on the muscle tissue $\mathrm{pH}$ and protein hydration. $\mathrm{Ca}$ and $\mathrm{Mg}$ contribute to maintenance of osmotic pressure and electrolyte balance in cells and tissues; thus, they play a vital role in regulation of the meat hydration level [54]. There were strong correlations between the microelement content (in particular $\mathrm{Cu}$ and $\mathrm{Fe}$ ) in the liver and in the breast and drumstick muscles in the broiler chickens fed with the BSR additive. The liver is characterized by substantially higher accumulation of microelements, especially $\mathrm{Fe}$ and $\mathrm{Cu}$, than that in other organs. A similar phenomenon was also observed by Stef et al. [27], who found significant correlations between the content of $\mathrm{Fe}-\mathrm{Zn}, \mathrm{Fe}-\mathrm{Cu}, \mathrm{Zn}-\mathrm{Fe}$, and $\mathrm{Cu}-\mathrm{Fe}$ in the liver of broiler chickens, regardless of the type of diet. Such correlations between microelements are not confined to poultry; they have also been found in the case of the liver of wild- 
living animals, i.e., $\mathrm{Ca}-\mathrm{Fe}(-)$ and $\mathrm{Zn}-\mathrm{Cu}(-)$ in boars; $\mathrm{Ca}-\mathrm{Cu}$ $(-), \mathrm{Ca}-\mathrm{Fe}(-)$, and $\mathrm{Cu}-\mathrm{Fe}(+)$ in roe deer; and $\mathrm{Ca}-\mathrm{Cu}(-), \mathrm{Zn}-$ $\mathrm{Cu}$, and $\mathrm{Fe}(+)$ in hares [55].

The calculated correlation coefficients indicate relationships whose strength and direction are related to the physicochemical properties of the elements as well as antagonistic or synergistic effects, bioavailability, co-occurrence, and involvement with other components in the physiological and metabolic processes in the animal organism.

\section{Conclusions}

The use of the 2 and $2.5 \%$ addition of the B. serrata resin in the diets decreased the ether extract in the breast and drumstick muscles, as well as their calorific value. The BSR contributed to the increase in the Ca content in the analyzed tissues and the $\mathrm{Mg}$ content in the drumstick muscles and liver but decreased the muscular $\mathrm{Cu}$ and $\mathrm{Zn}$ (in drumstick muscles) retention. Although the present results confirm the beneficial effect of $B$. serrata resin on the dietary and nutritional value of poultry meat, they can be a starting point for further investigations aimed at elucidation of the mechanisms of the impact of the phytobiotic on the broiler chicken organism.

Compliance with Ethical Standards The experiment was carried out after approval by the Second Local Ethics Committee at the University of Life Sciences in Lublin, Poland (No. 27/2014)

Conflict of Interest The authors declare that they have no conflicts of interest.

Open Access This article is distributed under the terms of the Creative Commons Attribution 4.0 International License (http:// creativecommons.org/licenses/by/4.0/), which permits unrestricted use, distribution, and reproduction in any medium, provided you give appropriate credit to the original author(s) and the source, provide a link to the Creative Commons license, and indicate if changes were made.

\section{References}

1. Cho JH, Kim HJ, Kim IH (2014) Effects of phytogenic feed additive on growth performance, digestibility, blood metabolites, intestinal microbiota, meat color and relative organ weight after oral challenge with Clostridium perfringens in broilers. Livest Sci 160:82-88

2. Alfaig E, Angelovicova M, Kral M, Vietoris V, Zidek R (2013) Effect of probiotics and thyme essential oil on the texture of cooked chicken breast meat. Acta Sci Pol Technol 12:379-384

3. Kirkpinar F, Ünlü HB, Serdaroğlu M, Turp GY (2014) Effects of dietary oregano and garlic essential oils on carcass characteristics, meat composition, colour, $\mathrm{pH}$ and sensory quality of broiler meat. Br Poult Sci 55:157-166

4. Zeng Z, Zhang S, Wang H, Piao X (2015) Essential oil and aromatic plants as feed additives in non-ruminant nutrition: a review. J Anim Sci Biotechnol 6:1-10
5. Herkel R, Gálik B, Bíro D, Rolinec M, Šimko M, Juráček M, Arpášová H, Wilkanowska A (2016) The effect of a phytogenic additive on nutritional composition of turkey meat. J Central Eur Agric 17:25-39

6. Ammon HPT (2010) Modulation of the immune system by Boswellia serrata extracts and boswellic acids. Phytomedicine $17: 862-867$

7. Camarda L, Dayton T, Di SV, Pitonzo R, Schillaci D (2007) Chemical composition and antimicrobial activity of some oelegum resin essential oil from Boswellia spp. (Burseraceae). Ann ChimRome 97:837-844

8. EURFA (2016) European Union Register of Feed Additives pursuant Regulation (EC) No 1831/2003. Annex I: List of additives. Eddition 244 [Online]. Available at: https://ec.europa.eu/ food/sites/food/files/safety/docs/animal-feed-eu-reg-comm register_feed_additives_1831-03.pdf(verified 10 November 2016)

9. Kiczorowska B, Al-Yasiry ARM, Samolińska W, Marek A, Pyzik E (2016a) The effect of dietary supplementation of the broiler chicken diet with Boswellia serrata resin on growth performance, digestibility, and gastrointestinal characteristics, morphology, and microbiota. Livest Sci 191:117-124

10. Kiczorowska B, Samolińska W, Al-Yasiry ARM, KowalczykPecka D (2016b) Effect of Boswellia serrata dietary supplementation on growth performance, gastrointestinal microflora, and morphology of broilers. Ann Anim Sci 16:835-849

11. Tabatabaei SN (2016) Effect of olibanum (Boswellia thurifera) as a feed additive on performance, some blood biochemical and intestinal morphology in broiler chicks. Res Opin Anim Vet Sci 6:130 134

12. Aviagen (2014) Ross 308 broiler: nutrition specifications. http://en. aviagen.com/assets/Tech Center/Ross Broiler/ Ross308BroilerNutritionSpecs2014-EN.pdf Accessed April 2016

13. Ziołecki J, Doruchowski W (1989) The method of assessment of slaughter poultry. COBRD Publishing, Poznań, Poland (in Polish)

14. AACC (2000) Approved methods of the AACC, 10th edn. American Association of Cereal Chemists, The Association, St. Paul, Minnesota, US

15. Polish Norm PN-EN ISO 6869 (2002) Determination of trace elements - determination of calcium, copper, iron, magnesium, manganese, potassium, sodium and zinc by atomic absorption spectrometry (AAS) after dry ashing (in Polish). Polish Committee for Standardization, Warsaw, Poland

16. Polish Norm PN-76/R-64781 (1976) Feed. Determination of phosphorus content (in Polish). Polish Committee for Standardization, Warsaw, Poland

17. StatSoft, Inc (2011) STATISTICA (data analysis software system). version 10. www.statsoft.com

18. USDA. US Department of Agriculture (2016) Agricultural Research Service, Nutrient Data Laboratory. USDA National Nutrient Database for Standard Reference, Release 28. Version Current: September 2015. http://www.ars.usda.gov/ba/bhnrc/ndl. Accessed 6 June 2016

19. Basch E, Boon H, Heerema TD, Foppo I, Hashmi S, Hasskarl J, Sollars D, Ulbricht C (2004) Boswellia: an evidence-based systematic review by the natural standard research collaboration. J Herbal Pharmacotherapy 4:63-83

20. Al-Yasiry ARM, Kiczorowska B (2016) Frankincense - therapeutic properties. Postepy Hig Med Dosw 70:380-391

21. Singh P, Chacko KM, Aggarwal ML, Bhat B, Khandal RK, Sultana S, Kuruvilla BT (2012) A-90 day gavage safety assessment of Boswellia serrata in rats. Toxicology Int 19:273-278

22. Gokaraju G, Gokaraju R, Gottumukkala V, Somepalli V (2005) New dietary supplement composition for obesity and inflammation U.S. Patent Application No. 11/155,486

23. Ahangarpour A, Heidari H, Fatemeh RAA, Pakmehr M, Shahbazian H, Ahmadi I, Mombeini Z, Mehrangiz BH (2014) 
Effect of Boswellia serrata supplementation on blood lipid, hepatic enzymes and fructosamine levels in type2 diabetic patients. $\mathrm{J}$ Diabetes Metabolic Disorders 13:11-18

24. Verma RK, Paraidathathu T (2014) Herbal medicines used in the traditional Indian medicinal system as a therapeutic treatment option for overweight and obesity management: a review. Int J Pharm Pharm Sci 6:40-47

25. Hamidpour SH, Hamidpour M, Shahlari M, Hamidpour R (2015) Chemistry, pharmacology and medicinal property of frankincense (Boswellia species): from the selection of traditional applications to the novel phytotherapy for the prevention and treatment of serious diseases. Global J Med Res 15:1-9

26. Fasinu PS, Bouic PJ, Rosenkranz B (2012) An overview of the evidence and mechanisms of herb-drug interactions. Front Pharmaco 3:1-19

27. Stef DS, Gergen I (2012) Effect of mineral-enriched diet and medicinal herbs on $\mathrm{Fe}, \mathrm{Mn}, \mathrm{Zn}$, and $\mathrm{Cu}$ uptake in chicken. Chem Cent J 6:1-9

28. Iranparast F, Parsaei S, Houshmand M, Naghiha A (2014) The effect of oral consumption of guggul (Commiphora mukul) resin on performance and humoral immunity response of broilers. Int $\mathrm{J}$ Adv Biol Biom Res 2:802-810

29. Kumar M, Kumar V, Roy D, Kushwaha R, Vaiswani S (2014) Application of herbal feed additives in animal nutrition - a review. Int J Livest Res 4:1-8

30. Proszkowiec-Weglarz M, Angel R (2013) Calcium and phosphorus metabolism in broilers: effect of homeostatic mechanism on calcium and phosphorus digestibility. J Appl Poult Res 22:609-627

31. Choi KC, Jeung EB (2008) Molecular mechanism of regulation of the calcium-binding protein calbindin-D9k, and its physiological role(s) in mammals: a review of current research. J Cell Mol Med 12:409-420

32. Dolińska B, Woźniak D, Ryszka F (2009) Intestinal calcium absorption. Farm Przegl Nauk 10:35-38 (summary in English)

33. Guo Y, Zhang G, Yuan J, Nie W (2003) Effects of source and level of magnesium and vitamin $\mathrm{E}$ on prevention of hepatic peroxidation and oxidative deterioration of broiler meat. Anim Feed Sci Tech 107:143-150

34. Shastak Y, Rodehutscord M (2015) A review of the role of magnesium in poultry nutrition. World Poultry Sci J 71:125-138

35. Bao YM, Choct M, Iji PA, Bruerton K (2007) Effect of organically complexed copper, iron, manganese, and zinc on broiler performance, mineral excretion, and accumulation in tissues. J Appl Poult Res 16:448-455

36. Soni N, Mishra SK, Swain R, Das A, Chichilichi B, Sethy K (2013) Bioavailability and immunity response in broiler breeders on organically complexed zinc supplementation. Food Nutr Sci 4:1293-1300

37. Richards JD, Zhao J, Harrell RJ, Atwell CA, Dibner JJ (2010) Trace mineral nutrition in poultry and swine. Asian Austral J Anim Sci 23:1527-1534

38. Świątkiewicz S, Arczewska-Włosek A, Jozefiak D (2014) The efficacy of organic minerals in poultry nutrition: review and implications of recent studies. World Poultry Sci J 70:475-486

39. Kim JW, Kim JH, Shin JE, Kil DY (2016) Relative bioavailability of copper in tribasic copper chloride to copper in copper sulfate for laying hens based on egg yolk and feather copper concentrations. Poultry Sci pew049. doi:10.3382/ps/pew049

40. Mohite BV, Chaudhari GA, Ingale HS, Mahajan VN (2013) Effect of fermentation and processing on in vitro mineral estimation of selected fermented foods. Int Food Res J 20:1373-1377
41. Surai PF (2014) Polyphenol compounds in the chicken/animal diet: from the past to the future. J Anim Physiol An N 98:19-31

42. Wójcik A, Pomianowski JF, Tońska E, Sowińska J, Mituniewicz T, Witkowska D, Chorąży Ł, Piotrowska J, Kwiatkowska-Stenzel A, Rudnicki Z, Murawska D, Mielcarek S (2012) Content of selected minerals in meat derived from broiler chickens subjected to various pre-slaughter handling procedures. Zywn-Nauk Technol Ja 19:164174

43. Starčević K, Krstulović L, Brozić D, Maurić M, Stojević Z, Mikulec Ž, Bajić M, Mašek T (2015) Production performance, meat composition and oxidative susceptibility in broiler chicken fed with different phenolic compounds. J Sci Food Agr 95:11721178

44. Giannenas I, Tzora A, Bonos E, Sarakatsianos I, Karamoutsios A, Anastasiou I, Skoufos I (2016) Effects of dietary oregano essential oil, laurel essential oil and attapulgite on chemical composition, oxidative stability, fatty acid profile and mineral content of chicken breast and thigh meat. Eur Poultry Sci 80. doi:10.1399/eps.2016. 134

45. Afsana K, Shiga K, Ishizuka S, Hara H (2004) Reducing effect of ingesting tannic acid on the absorption of iron, but not zinc, copper and manganese in rats. Biosci Biotechnol Biochem 68: 584-592

46. Grashorn MA (2010) Use of phytobiotics in broiler nutrition-an alternative to infeed antibiotics. J Anim Feed Sci 19:338-347

47. Doyle JJ (1980) Genetic and nongenetic factors affecting the elemental composition of human and other animal tissues - a review. $\mathrm{J}$ Anim Sci 50:1173-1183

48. Zapata JFF, Moreira RS, Dos R, Fuentes MDFF, Sampaio EM, Morgano M (1998) Meat mineral content in broilers fed diets without mineral and vitamin supplements. Pesqui Agropecu Bras 33: $1815-1820$

49. Lombardi-Boccia G, Lanzi S, Aguzzi A (2005) Aspects of meat quality: trace elements and vitamins in raw and cooked meats. J Food Comp Anal 18:39-46

50. Taranu I, Marin DE, Untea A, Janczyk P, Motiu M, Criste RD, Souffrant WB (2012) Effect of dietary natural supplements on immune response and mineral bioavailability in piglets after weaning. Czech J Anim Sci 57:332-343

51. Samolińska W, Grela ER (2016) Comparative effects of inulin with different polymerization degrees on growth performance, blood trace minerals, and erythrocyte indices in growing-finishing pigs. Biol Trace Elem Res. doi:10.1007/s12011-016-0796-y

52. Połtowicz K, Doktor J (2013) Macromineral concentration and technological properties of poultry meat depending on slaughter age of broiler chickens of uniform body weight. Anim Sci Papers Rep 31:249-259

53. Goluch Z, Gardzielewska J, Natalczyk-Szymkowska W, Stoltman W, Cyran A (1997) The Pb, Cd, Fe, Cu and $\mathrm{Zn}$ content in muscles of broiler chickens kept under farm conditions. Zeszyty Naukowe Przeglądu Hodowlanego (Chów i Hodowla Drobiu) 32:265-272 (summary in English)

54. Houston MC, Harper KJ (2008) Potassium, magnesium, and calcium: their role in both the cause and treatment of hypertension. J Clin Hypertens 10:3-11

55. Długaszek M, Kopczyński K (2011) Comparative analysis of liver mineral status of wildlife. Probl Hig Epidemiol 92:859-863 (summary in English) 